\title{
3. En felles nåtid - en felles fremtid? En analyse av Øyvind Rimbereids «Solaris korrigert»
}

\section{Per Thomas Andersen}

Sammendrag Kapitlet løfter frem tekster av filosofer som Hannah Arendt, Arne Næss og Peter Wessel Zapffe, som alle er interessevekkende i sammenheng med temaet bærekraftig utvikling. Kapitlet tar et historisk-teoretisk perspektiv. Global solidaritet, også for fremtidens mennesker, fremheves som sentralt i møte med læreplanenes formuleringer omkring bærekraftig utvikling. Gjennom en analyse av Øyvind Rimbereids dikt «Solaris korrigert» tydeliggjøres det hvordan diktet er et treffende eksempel på litteratur som utgangspunkt for arbeid med bærekraftig utvikling i skolen.

Nøkkelord økokritikk | bærekraftig utvikling I science fiction | dystopi | Øyvind Rimbereid

\begin{abstract}
This chapter focuses on philosophers such as Hannah Arendt, Arne Næss and Peter Wessel Zapffe, who all are relevant in the approach of the theme of sustainable development. The chapter has therefore an historical theoretical perspective. Global solidarity, also for future generations, is pointed out as central in relation to the curriculum's formulations about sustainable development. Through an analys of «Solaris korrigert» (Solaris corrected), it is made explicit how the poem is an example of how literature may be used as a point of departure for the work with sustainable development in school.
\end{abstract}

Keywords ecocritisism I sustainable development I science fiction I dystopian literature | Øyvind Rimbereid 
I en liten artikkel fra 1957 skriver filosofen Hannah Arendt at «for første gang i historien lever alle mennesker på jorden i en felles nåtid» (Arendt 2010, s. 47). Alle land er blitt hverandres nabo. Vi merker ettervirkninger av begivenheter som finner sted på den andre siden av kloden. Men, sier hun, denne felles nåtid er ikke basert på en felles fortid og garanterer på ingen måte en felles fremtid. Teknologien som har frembrakt verdens enhet, kan like lett komme til å ødelegge den. Da Arendt skrev denne artikkelen, var det sterkeste symbolet for det nye skjebnefellesskapet atombomben. Den skapte en form for negativ solidaritet, mente hun, nemlig frykten for global destruksjon. Global solidaritet kunne kun bli positiv, hevdet Arendt, hvis den ble knyttet til politisk ansvar. Hun mente det var maktpåliggende at det globale skjebnefellesskap, helt uavhengig av personlig skyld, førte til en form for «verdensborgerskap» - ikke til nasjonalistisk isolasjon, politisk apati eller desperat opprør.

Den nye felles nåtid Arendt beskrev, det nye naboskap, er blitt aktualisert flere ganger i tiden etter andre verdenskrig. Atomtrusselen var utvilsomt det første sjokket for etterkrigsgenerasjonen, men senere ble overbefolkningen et like påtrengende problem, og fra 1970-tallet og fremover har miljøproblemer, forurensning, utslipp og global oppvarming kommet like sterkt i søkelyset. Det virker ikke urimelig, som Arendt presiserer, at vi lever i en felles nåtid, en slags skjebnetid der det fremdeles er muligheter for å handle ansvarlig og politisk på vegne av det globale fellesskap. De ulike nasjoner og kulturer har ulik historie og fortid, vi kommer fra ulike fellesskapsformer, og overhengende utfordringer gjør det usikkert om vi egentlig kan forvente en felles fremtid. Men vi har en felles nåtid der det fremdeles er mulig å unngå den usikre fremtiden. Men da må vi trolig handle, som Arendt sier, som globale naboer i et nytt «verdensborgerskap». Vi må øve oss i å delta aktivt i det globale naboskap.

Det kan vi gjøre gjennom utdanning, læring og kunnskapstilegnelse. Skolen er en av de viktigste arenaer for å utvikle bevisstheten om en felles nåtid (som kanskje også er en nådetid) og om et globalt fellesskap som er premiss for medvirkning og medansvar i møte med en usikker fremtid.

I det oppdaterte læreplanverket fra Utdanningsdirektoratet er «demokrati og medborgerskap» og «bærekraftig utvikling» berørt blant annet i det som kalles «tverrfaglige temaer». I omtalen av disse tverrfaglige temaene er den overordnede delen av læreplanverket også åpen for «innsikt i utfordringer og dilemmaer innenfor temaene» (Kunnskapsløftet 2020, Overordnet del, Tverrfaglige temaer). Dette kapitlet skal handle om noen slike utfordringer og mulige dilemmaer. Artikkelen drøfter den potensielle motsetningen mellom ideen om «medborgerskap» (verdensborgerskap), det vil si «menneskeheten» som aktør i det Arendt kaller «verdenshistorien» - og det økokritiske perspektivet der «menneskeheten» ser ut til å spille en problematisk rolle (jfr. ideen om den antropocene tidsalder). Kapitlet 
viser til enkelte filosofiske og litterære eksempler som kan bidra til å illustrere de nevnte utfordringene og dilemmaene. Hovedeksemplet er fra Øyvind Rimbereids diktsamling Solaris korrigert (2004). ${ }^{1}$

\section{FILOSOFER, FORSKERE OG FORFATTERE}

Klimaendringer må observeres over lang tid, fakta må samles systematisk, det må føres statistikk, og endringer må beskrives. Ellers kan vi ikke vite det vi tror. Slike klimaobservasjoner er blitt gjort i langt over 100 år. Derfor vet vi at det har skjedd store endringer. $\mathrm{CO}_{2}$-utslipp i atmosfæren fører til at den globale temperaturen øker. Havet stiger og blir surere. Isen ved polene smelter. Det blir mer nedbør og ekstremvær, men også mer tørke og store skogbranner.

Alle disse endringene er blitt observert og overvåket av de faktabaserte vitenskapene, av meteorologer og klimaforskere. Hvilke bidrag har vi å komme med fra de humanistiske og samfunnsfaglige vitenskapene? Hva betyr det at filosofer, forfattere og i et videre perspektiv også lærere, foreldre og elever engasjerer seg?

De fakta som forskere har observert, viser en tydelig utvikling over tid. Men vi kjenner ikke noe endelig sluttpunkt for utviklingen. Vi vet ikke hvordan det vil ende. For å påvirke utviklingen er det derfor avgjørende hva slags holdninger befolkninger, beslutningstakere og enkeltindivider utvikler. Slike holdninger er det ikke bare meteorologer og klimaforskere som kan ta ansvar for. Det er et ansvar alle må ta i fellesskap. Selvfølgelig har politikere og ledere i ulike samfunnssektorer et særskilt ansvar. Men det er nærliggende å tenke at alle må ta et felles ansvar for en felles fremtid.

\section{HOLDNING OG HANDLING}

I Norge er det påfallende at blant de fremste pionerene som ofte kalles «firstwave»-økologer, finner vi nettopp filosofer og forfattere. De representerer ulike holdninger og har hatt ulik innflytelse. Det viktigste bidraget kom utvilsomt fra filosofen Arne Næss, som i 1973 utga Økologi, samfunn og livsstil. Han kalte sin tenkning økosofi. Hans «dypøkologiske» bidrag inngår fortsatt i internasjonale økokritiske antologier. Økologiboken kom i mange opplag og skapte grunnlag for et bredt engasjement, ikke minst blant den tidens unge. Verket var vitenskapelig velinformert, men like viktig var de holdningene verket formidlet når det gjaldt menneskets plass i naturen og i forhold til andre skapninger på kloden. Boken var

1 Dette kapitlet er en revidert versjon av kapitlet om «Solaris korrigert» i Andersen, Per Thomas 2018. Rimbereids lyrikk. Hendelser og poetiske øyeblikk. Fagbokforlaget, Bergen. 
velbalansert, veloverveid og etisk grunnfestet - samtidig som holdningene samsvarte med et aksjonistisk engasjement fra Næss' side. Næss' verk var preget av en dyp respekt for klodens ulike livsformer - men med plass for mennesket. Boken startet med en ganske presis situasjonsbeskrivelse:

Hvis man i få ord forsøker å si hva det er som gjør situasjonen særlig kritisk, foreslår jeg: Opphopningen av eksponentielt tiltagende, tilnoermelsesvis eller totalt irreversible miljøforringelser eller ødeleggelser fremkalt ved en dypt forankret materiell produksjons- og forbruks-ideologi og -praksis (Næss 1973, s. 11. Kursivert i originalen).

En annen holdning ble presentert av filosofikollega og klatrekamerat (de var begge lidenskapelige fjellklatrere) Peter Wessel Zapffe. Hans bidrag ble først og fremst utformet i verket $\mathrm{Om}$ det tragiske fra 1941 og ga uttrykk for en dyp pessimisme. Hans utgangspunkt var at mennesket karakteriseres ved sin overutrustning i forhold til det biologisk nødvendige. Derfor passer mennesket ikke inn i naturen. Selv når alle våre biologiske behov er dekket, har vi et overskudd som blir brukt til lek, oppfinnelse og teknologiske nyskapelser som etter hvert har kommet ut av kontroll og nå henger over oss som trusler. Dette gjør mennesket til klodens tragiske skapning. Vi utgjør en livsform som er til skade for både oss selv og resten av kloden. Som følge av denne tragiske situasjonen var Zapffe såkalt anti-natalist. Han mente løsningen måtte være at menneskene sluttet å lage barn, med andre ord: Mennesket måtte utslette seg selv av hensyn til resten av kloden.

Zapffe fikk ikke tilnærmelsesvis den samme innflytelsen som Næss. Han nevnes her først og fremst som en representant for den dypt pessimistiske holdning som også fins på vegne av menneskeheten blant dem som er bekymret for miljøødeleggelsene. Slike pessimistiske holdninger finner man også blant «first-wave»-forfatterne i Norge. Et av de fremst verkene fra 1970-tallet som handler om økologisk krise, var Knut Faldbakkens dobbeltroman Uår. Aftenlandet (1974) og Uår. Sweetwater (1976). Handlingen er lagt til en gang i fremtiden, etter at sivilisasjonen slik vi kjenner den, har brutt sammen. En gruppe mennesker flytter ut på en søppelplass og forsøker å ta vare på rester av menneskeslektens verdier i kritisk kontrast til det dehumaniserte overflodssamfunnet. Romanene er en dystopisk fortelling. I motsetning til Zapffes filosofiske pessimisme kan fremstillingen hos Faldbakken altså forstås som en engasjert advarsel til leserne om at vi må endre kurs. Pessimismen er ikke prinsipiell, men retorisk og strategisk.

Faldbakkens romaner tilhører en sjanger som senere har fått betegnelsen cli-fi. Cli-fi er en forkortelse for climate-change-fiction, og begrepet er etablert etter møn- 
ster av science fiction. Den samme sjangerbruken finner man hos en av de fremste «second-wave» økokritiske forfatterne, Øyvind Rimbereid, som i diktet «Solaris korrigert» (2004) også skildret et fremtidssamfunn slik det arter seg i 2848. «Solaris korrigert» skal være det litterære eksemplet i denne artikkelen. Både Faldbakken og Rimbereid bruker dystopien som fortellingsform, det vil si en oppdiktet fortelling om et fremtidig skrekksamfunn. Dystopien er nært i slekt med apokalyptiske fortellinger. De forteller om verdens undergang, i gamle tekster oftest i et religiøst perspektiv, men i moderne sammenhenger kan apokalypse også betegne forestillinger om kommende ulykker eller naturkatastrofer. I The Environmental Imagination: Thoreau, Nature Writing and the Formation of American Culture (1995) skriver Lawrence Buell at «Apocalypse is the single most powerful master metaphor that the contemporary environmental imagination has at its disposal» (s. 285). I Ecocriticism (2012), en mye brukt bok om økokritikk, har Greg Garrard et kapittel med tittelen «Environmental apocalypticism». Der henviser han nettopp til Buell. Han påviser også at apokalyptisk retorikk inngår i mange moderne miljøforkjemperes fremstillinger, blant annet i Al Gores Earth in the Balance (1992). Apokalyptiske forestillinger går imidlertid helt tilbake til den iranske profeten Zoroaster, til profeten Amos, og de er en integrert del av blant annet jødisk og kristen religion. I sekulær diktning spiller samme typer forestillinger en viss rolle hos Wordsworth, Blake, T. S. Eliot og D. H. Lawrence. I moderne science fiction-filmer inngår ofte apokalyptiske elementer både i komedier og i mer skremmende kontekster (Dr. Strangelove, Star Wars, Apokalypse nå!).

\section{«APOKALYPTSEN SKREIKMARE», OM «SOLARIS KORRIGERT»}

Øyvind Rimbereids langdikt «Solaris korrigert» fra samlingen med samme navn er en fortelling om fremtidens Stavanger, men fremstillingen er verken en revitalisering av regionallitteraturen, en ny heimstaddiktning eller et nasjonalt prosjekt. Det er forbindelsene mellom det lokale, det globale og den nye makroregionen rundt oljevirksomheten i Nordsjøen som er gjenstand for Rimbereids fremstilling. Diktet er kanskje den mest originale skjønnlitterære teksten i Norge hittil i vårt århundre. Det dreier seg om en poetisk science fiction der oljevirksomheten i Nordsjøen blir betraktet i en retrospektiv vinkel, formidlet i et nyoppfunnet fremtidsspråk.

Solaris korrigert ble svært positivt mottatt av anmelderne da verket kom ut i 2004. Paal-Helge Haugen skrev for eksempel i Fædrelandsvennen at «det kommer ut bøker som dette bare en gang pr. generasjon». Rimbereid ble tildelt Kritikerpri- 
sen for diktsamlingen. Men verket har en betydelig resepsjonshistorie også utover dagskritikken. Mest spektakulær var Det norske teaterets oppsetning av en sceneversjon i oktober 2015 med Ane Dahl Torp som skuespiller og regi av Peer Perez Øian. Allerede i 2013 hadde imidlertid Den norske opera satt opp en operaversjon med musikk av Øyvind Mæland. Ytterligere en sceneversjon ble vist på Vitenfabrikken i Sandnes i 2014 produsert av Lene Aareskjold og Grethe Mo.

Innen litteraturforskningens felt er det også levert flere bidrag. Janike Kampevold Larsen skrev en artikkel i Vinduet i 2004, «For jeg vet eksistensen av verden», der hun tok opp den intertekstuelle forbindelsen til Stanislav Lems og Andrej Tarkovskijs Solaris. Audun Lindholm skrev en utmerket presenterende artikkel i Vagant og i boken Norsk littercer kanon i 2008. I 2010 skrev Christian Refsum om språket $\mathrm{i}$ «Solaris korrigert», «Flerspråklighet i nyere skandinavisk litteratur: Jonas Hassan Khemiri og Øyvind Rimbereid». Artikkelen ble publisert i Edda. Thorstein Norheim skrev særlig om dystopiske trekk ved diktet i presentasjonsartikkelen «'Picts av univers parallell'. Om samtidslyrikk i Norge 2000-2010» (2015). Norheim karakteriserer «Solaris korrigert» som et dikt som «kombinerer historie- og samfunnsspørsmål med den språklige hybridisering» (Norheim 2015, s. 25). Innfallsvinkelen til hans omtale er Rafaella Baccolini og Tom Moylans begrep «critical dystopias» (Norheim 2015, s. 29). Endelig skrev Claus K. Madsen en sjangerorientert artikkel i Edda 2015, «To aspekter af helhed og to typer langdigte. En afprøvning af Jacobsons poesiformalisering på Høecks 'Ulrike Marie Meinhof og Rimbereids 'Solaris korrigert'».

Enkelte berøringspunkter fins det naturlig nok mellom disse analysene. Men først og fremst er analysene forskjellige og bidrar dermed til å demonstrere hvor rikt på perspektiver Rimbereids verk er. Hva har oljen gjort med oss? Timothy Mitchell skriver i artikkelen «Hydrocarbon Utopia» fra boken Utopia/Dystopia. Conditions of Historical Possibility (2010):

Fossil fuels have played an ambiguous role in our utopian imagination. In the twentieth century they helped to form the most prosperous, healthy, and democratic communities in human history. They enabled these communities to live according to the utopian principle that growth of wealth and well-being could continue without any foreseeable limit. Yet hydrocarbon energy also now appears as a curse. Oil is said to be a cause of violence and war. Societies that process it in abundance appear more liable to suffer from a special degree of tyranny (Mitchell 2010, s. 117). 
I Rimbereids fremstilling er det ikke så mye krig, vold og tyranni som preger fremstillingen, ennskjønt det er gjort god plass for tradisjonelle science fiction-motiver som økt overvåkning og «korrex». Men, som det heter i innledningen til Utopia/ Dystopia: «Utopias and dystopias are histories of the present» (Gordin et al. 2010, s. 1), og Rimbereids verk kan etter mitt skjønn opplagt leses som en advarsel vedrørende det utopiske bildet som tegnes av oljeproduserende land i sitatet ovenfor. Norge er siden 1990-årene, slik jeg ser det, opplagt blitt innfanget av forestillinger om «growth of wealth and well-being (...) without any forseeable limit». Trusselbildet for oss er imidlertid ikke krig og tyranni à la dagens Midtøsten, men global $ø$ kologisk krise. Også den blir beskrevet av Mitchell:

These ways of life are unsustainable, and they now face the twin crises that will end them: although calculating reserves of fossil fuels is a political process involving rival calculative techniques, there is substantial evidence that those reserves are running out, and in the process of using them up, we have taken carbon that was previously stored underground and placed it in the atmosphere, where it is causing increases in global temperatures that may lead to catastrophic climate change (Mitchell 2010, s. 118).

Tony Burns skriver i Political Theory, Science Fiction and Utopian Literature at i historien om fremtidsskildringer er H. G. Wells' bidrag avgjørende: «Wells' science fiction is important for the history of utopian/dystopian political thought because, after nearly 500 years of utopianism, it marked a major transition from utopian to dystopian writing» (Burns 2008, s. 19). Både begrepet utopi og begrepet dystopi konsentrerer seg om steder, topos, og Rimbereids diktning er klart topografisk. Likevel; dystopiske science fiction-fortellinger handler like mye om hendelser, hendelser med virkninger som overskrider sine årsaker, hendelser som representerer grunnleggende epokale endringer av irreversibel karakter. Poenget i dystopiske fremstillinger er oftest å sette søkelyset på slike historiske begivenheter som ligger mellom nå og den projektive fremtiden, begivenheter som har skjedd i fiksjonen, men som ikke bør skje i historien.

Det er særlig to viktige hendelser som ligger til grunn for fremstillingen $i$ «Solaris korrigert», en relativt hurtig og en meget langsom. Den hurtige hendelsen er den historiske endringen av region og nasjon som fant sted i og med oljevirksomheten i Nordsjøen. Den startet forsiktig på 1960-tallet, men skjøt dernest fart og forandret landet med hensyn til økonomi og velferd i løpet av en generasjon. I Rimbereids fremstilling er konsekvensene av denne hendelsen forlenget projektivt inn i fremtiden til år 2480, og en ny, fiktiv hendelse er ekstrapolert inn i teksten, 
nemlig avslutningen av «oljeeventyret». Det velstandssamfunnet vi kjenner fra vår egen tid, er definitivt tapt.

Den langsommere hendelsen som ligger til grunn for fremstillingen, er rent fiktiv og handler om endring av språket som følge av påvirkning fra de omkringliggende språkområdene. Endringene er skildret fra en avstand på 476 år. Mens den første av disse hendelsene har avgjørende betydning for tematikk og valg av motiver i diktet, har den andre bestemt det språklige uttrykk i diktet. Det dreier seg om et poetisk språk skapt ene og alene for dette verket, kanskje i en intertekstuell tradisjon fra James Joyces Finnegans Wake (1939). Men Rimbereids verk er tross alt mye lettere å lese. Språket kan symbolisere den utviklingen som skal ha skjedd i makroregionen. Stavangerdialekten er grunnstammen i språket, men i tillegg finner vi viktige elementer fra engelsk, tysk og muligens flere andre språk. Språket er karakterisert ved hurtige kodevekslinger mellom språk og en rekke forkortelser, utelatelse av en del vokaler og dessuten ved at de skandinaviske bokstavene æ, ø og å er eliminert. Audun Lindholm beskriver Solaris-språket på følgende måte i sin artikkel i tidsskriftet Vagant fra 2008:

Rimbereid har trukket en språklig sirkel rundt Ekofisk, denne første plattformbyen midt i Nordsjøen, og skapt en hybrid syntese av stavangerdialekt, lavlandsskotsk, engelsk, nederlandsk og dansk, med oldnorske former blandet inn (Lindholm 2008).

All fiksjonslitteratur om fremtiden stiller leseren overfor en paradoksal oppgave, nemlig å «rekonstruere» noe som ikke har skjedd ennå. Skrivetidspunktet og lesetidspunktet utgjør et (eller to) utgangspunkt som projeksjonen av et fremtidig tidspunkt må tolkes ut ifra, det vil si at det gir oss tolkningsredskaper som per definisjon er utilstrekkelige. Projeksjonspunktet i fremtiden byr på diskrepanser som ofte ikke blir forklart ved hjelp av historiske utviklingslinjer. Diskrepansen utvikler seg ikke gradvis, slik de gjør i historien, men er der brått, uten forberedelse. Derfor fremstår de som underliggjorte tilstander, fenomener eller situasjoner. Hva som har skjedd mellom disse tidspunktene, må leseren forsøke å «rekonstruere» til tross for at de ikke har skjedd ennå. Selve grunnideen er vel så mye i mange tilfeller at denne "rekonstruksjonen» av mulige hendelser skal fremkalle noen bestemte typer refleksjon hos leseren, ofte med skremmende eller advarende virkning i forhold til leserens nåtid. I tradisjonell science fiction vil disse refleksjonene ofte være blandet med en futuristisk fascinasjon, gjerne av teknologisk karakter. I Rimbereids tilfelle er det lite fascinasjon å finne, bortsett fra den estetiske fascinasjonen ved et språklig eksperiment. I dette faktum ligger det at Rimbereids verk plasserer 
seg langt over mot det dystopiske. Og det er hos Rimbereid som hos de fleste dystopikere: Leseren må «rekonstruere» katastrofiske hendelser. Heri ligger kanskje «Solaris korrigert»s didaktiske potensial. Den fremtidssituasjonen som skildres, er prognostisk. Den bygger på fenomener i nåtiden og fremstilles som sannsynlig hvis man forlenger utviklingen inn i fremtiden. Forfatteren forlenger og forsterker tendenser ved skrivetidspunktet. Hos Rimbereid er det prognostiske aspektet enkelt og har støtte i forskningsfakta i nåtiden. Fenomenet han bygger på, er oljeutvinningen i Nordsjøen. Det prognostiske aspektet er at oljebrønner og gassbrønner kommer til å bli tømt. Det er ikke mer å hente, noe som åpenbart tenkes å bidra til at hele fremtidens samfunn endres.

Det samfunnet Rimbereid skildrer i «Solaris korrigert», er imidlertid så dramatisk annerledes enn vårt velkjente at det må ligge flere og andre begivenheter til grunn for endringene enn det isolerte faktum at olje- og gassvirksomheten har tatt slutt. Leseren blir nødt til å «rekonstruere» flere ukjente hendelser mellom nåtid og fremtid for å bringe mening i skildringene. Dette kan være krevende fordi teksten gir få konkrete holdepunkter. Men kanskje er det først og fremst ett overordnet punkt som har betydning dersom vi legger til grunn synspunktet til Michael D. Gordin et al.: «Utopias and dystopias are histories of the present» (Gordin et al. 2010, s. 1). Hva Rimbereids fremstilling mer enn noe annet får en til å reflektere over, er det samme hovedpoenget som vi finner i Timothy Mitchells artikkel om «Hydrocarbon Utopia» (2010): Det er sammenheng mellom petroleum og politikk, mellom energi og samfunn. Tar man i betraktning de samfunnsomveltninger som tidligere energiomlegginger har medført, er det kanskje ikke urimelig å tenke seg at noe tilsvarende kan skje når oljen tar slutt. Historien lærer oss at det ikke er sikkert vi bare kan fortsette som før - kun med bruk av nye energikilder.

\section{SOLENERGI}

Frem til 1800-tallet var energikildene fornybare. Sol og regn fikk vekster og trær til å gro, og ga føde til mennesker og dyr. «Solar energy was converted into grain and other crops to provide fuel for humans, into grasslands to raise animals for labour and further human fuel, into woodlands to provide firewood, and into wind- and waterpower to drive transportation and machinery», skriver Timothy Mitchell (Mitchell 2010 s. 119). Helt til langt innpå 1950-tallet ble det drevet jamvektig jordbruk med grunnlag i denne slags fornybar energi på de små øyene i Ryfylke der oljeplattformene og Condeepene ble slept forbi noen få år senere. Mitchell skriver også at «for most of the world, the capture of solar radiation in 
replenishable forms continued to be the main source of energy until perhaps the mid-twentieth century» (Mitchell s. 119).

Ute i Europa startet imidlertid en omlegging gradvis å finne sted fra og med begynnelsen av 1800-tallet. Vi snakker om en av de aller viktigste omveltningene i klodens historie: «From around 1800, however, these renewable sources were steadily replaced with highly concentrated stores of buried solar energy, the deposits of carbon laid down 150 to 350 million years ago, when the decay of peat-bog forests and of marine organisms in particular oxygen-deficient environments converted biomass into relatively rare but extraordinarily potent deposits of coal and oil» (Mitchell s. 119). Overgangen fra fornybare energikilder til kull og olje endret verden på nesten alle tenkelige måter, og frembrakte et utopisk energiforbrukende hundreår. Prognosene viser at vi kommer til å bruke opp disse ekstremt potente energikildene i perioden mellom 1950 og 2050, mer eller mindre samsvarende med Øyvind Rimbereids (og min egen) levetid. Vi er karbon-utopistene.

Forskjellene mellom tradisjonssamfunnenes solenergi og det moderne karbonbaserte energisamfunn er store med hensyn til både forbruk og fordeling. Mitchell skriver om forbruket:

A single liter of gasoline used today needed about twenty-five metric tons of ancient marine life as precursor material, and organic matter of equivalent of the earth's entire production of plant and animal life for four hundred years was required to produce the fossile fuels we burn in a single year (Mitchell s. 119).

Nesten like viktig som forbruket er fordelingen. Solen vandret selv over himmelen og leverte sin energi med relativt velfungerende fordeling over det meste av kloden. Transport av energi var ikke noe problem i tradisjonssamfunnene. Tradisjonell solenergi privilegerte mindre og spredte befolkningsgrupper der folk kunne bo tett på skog, åker og beiteområder. Solen gikk den samme gang på himmelen hvert døgn og hvert år, og påskyndet i liten grad til forandring.

Kull var en mye kraftigere energikilde. Den fantes imidlertid bare i konsentrerte mengder på noen få steder, særlig i Storbritannia, Tyskland og USA. Etter hvert som utvinningen av kull skjøt fart, førte dette til tidligere ukjente privilegier for de kullproduserende land med hensyn til både makt og rikdom. Kull var så potent at det viste seg langt mer kostnadssvarende å transportere enn det hadde vært med tømmer. Kull gjorde det også mulig å utvikle helt nye transportmidler som tog og dampskip. Det vokste frem et nettverk av transportveier for energi og nye knutepunkter for infrastruktur, alt under kontroll av de kullproduserende stormaktene. 
Kull satte imidlertid ikke bare fart i fremveksten av globalt privilegerte stormakter. Hele den komplekse og samfunnsendrende prosessen vi forbinder med industrialisering, er tett knyttet til bruken av kull som energikilde. Industrialiseringen var på sin side forbundet med nye bosetningsmønstre. Kullutvinning og industriproduksjon medførte fortetting av befolkningsgrupper og etter hvert en stadig $ø$ kende urbanisering. I forlengelsen av slike velkjente historiske prosesser fremkommer det også at energikilder ikke er politisk nøytrale. Fortettingen av store befolkningsmasser i privilegerte industriland førte til nye organisasjonsformer og nye politiske ideer. De nye gruvearbeiderne og ansatte i industrien organiserte seg i fagforeninger for å bedre sine kår - som i lang tid var ganske umenneskelige. Store deler av befolkningen ble trukket inn i opinionsdannende arbeid og interessekonflikter. Politiske partier i moderne forstand og arbeiderbevegelsen ble en del av den nye virkeligheten. Kort sagt: Kull er knyttet til demokratisering, klassekamp og kapitalisme «hjemme» i de industrialiserte land. «Ute» så det annerledes ut. Kull er også knyttet til kolonialisme. Med sin nye makt og de effektive transportbetingelsene kunne de privilegerte nasjoner ikke bare ta kontroll over, men også beholde og administrere territorier og befolkninger i fjerne strøk. Arbeidskraften i fjerne besittelser kunne også kontrolleres, styres og eventuelt flyttes etter behov mye lettere enn «hjemme», der fagforeningene etter hvert ytte betydelig politisk motstand ved å benytte seg av streik.

Politisk streik og sterke fagforeninger ble etter hvert oppfattet som et betydelig problem av fabrikkeiere og vekstdrevne nasjoner. Mitchell mener dette var en viktig årsak til at karbonepoken skiftet fra kull til olje:

After World War II, the coal miners of Europe again appeared as the core of a militant threat to corporatist democratic politics. As U.S. planners worked to engineer the postwar political order in Europe, they came up with a new mechanism to defeat the coal miners: to convert Europe's energy system from one based on coal to one based predominantly on oil. Western Europe had no oil fields, so the additional oil would come from the Middle East (Mitchell s. 122-123).

Fordi Midtøsten var et langt mindre demokratisert befolkningsområde enn de kullproduserende land, var det åpenbart langt lettere å disiplinere arbeidskraften i disse områdene. Ifølge Mitchell har svært mye av internasjonal politikk etter andre verdenskrig dreid seg om USAs behov for tilgang til og kontroll over oljeressurser. Den nye oljevirksomheten satte de europeiske kullarbeidernes makt ut av spill. Riktignok hadde også oljearbeiderne betydelig streikemakt. De tok den også i 
bruk. Likevel; antallet arbeidere var mindre når det gjaldt å utvinne energien, og de viktigste oljekildene lå i områder der man kunne bruke andre metoder med hensyn til å disiplinere arbeiderne enn i demokratiserte land. Igjen: Det er sammenheng mellom energi og styresett, i dette tilfellet mellom petroleum og politikk. Over tid viste det seg at petroleum er tettere knyttet til tyranni og krig enn tidligere energikilder. Diktaturstater i Midtøsten har produsert energi som storforbrukere i den demokratiserte verden har satt stor pris på, og ikke har hatt noen problemer med å inngå allianser med. Et nærliggende eksempel er alliansen mellom USA og Saudi-Arabia.

Olje er lettere enn kull og er derfor mye enklere å transportere. Det samme gjelder naturligvis for gass. Frakten foregår dels i gigantiske tankskip som kan krysse mellom alle kontinenter, dels i et stort rørledningsnettverk. Olje og gass passer som hånd i hanske til en globalisert tidsalder og har klart vært med på å frembringe den. Det er i lang tid blitt ansett som en gunstig løsning for de store energiforbrukerne at utvinningen hovedsakelig har funnet sted i fjerne områder, og er blitt fraktet «hjem» etter behov. Den politiske uro i de største oljeproduserende regioner har imidlertid begynt å bli så stor at problemene og kostnadene ved å opprettholde tilstrekkelig kontroll er blitt svært omfattende. Dette har ført til at land som USA har begynt å satse mer på oljeproduksjon hjemme.

USA har imidlertid helt fra starten av oljealderen vært den viktigste pådriveren i begjæret etter olje. Nesten i alle deler av verden har amerikanske oljeselskaper vært de fremste til å etablere og drive oljeutvinning. Norge er ikke noe unntak. Og det store behovet for energi skyldes blant annet den nye livsstilen for en stor og voksende middelklasse som utviklet seg i USA særlig fra 1940- og 1950-årene. Den idé at store befolkninger i privilegerte nasjoner skulle ha ubegrenset tilgang på energi for å forsyne en livsstil som ikke er bærekraftig, har så spredt seg over store deler av verden, først til Europa, dernest til Asia. Mitchell forteller historien om en samtale i 1948 mellom daværende forsvarsminister i USA, James Forrestal, og presidenten i selskapet Socony-Vacuum (senere Mobil Oil): Forrestal var bekymret for at «unless we have access to Middle East oil, American Motorcar companies would have to design a four-cylinder motorcar within the next five years» (s. 125). Det som skjedde, var at bilindustrien gikk motsatt vei; man byttet ut standard sekssylindermotorer med store, bensinslukende V8-maskiner. I Europa, derimot, laget Volkswagen den lille Boblen, britene designet Morris Mini, begge med små, firesylindrede motorer. Franskmennene bygget den legendariske 2CV. Disse småbilene var starten på spredningen av privatbilismen i Europa. Standard ble firesylindrede motorer. Mitchell kommenterer: 
The European vehicles outsold and outlasted the badly engeneered American cars. But the makers of the latter helped engeneer something larger. They manufactured the utopia of a carbon-heavy middle class American lifestyle, in which any concern about the cost of energy and its future availability dissolved away (Mitchell s. 125).

Denne livsstilen befinner seg fortsatt i en spredningsfase globalt, til tross for kunnskap om at den ikke er bærekraftig. Med tanke på det senmoderne forbrukersamfunnets ekstreme energiforbruk og den sterke avhengigheten av petroleum som energikilde er det neppe noen overdrivelse å anta at overgangen til en tid uten olje vil bli dramatisk. Historien viser at koblingen mellom energikilde og samfunnsforhold er tett.

\section{FRA UTOPI TIL DYSTOPI}

Historien har altså vist at energitype er tett knyttet til teknologi, arbeidsliv og transport. Energikilde har likeledes konsekvenser for bomønstre, organisasjonsformer og klassedeling av befolkningsgrupper. Det er nær forbindelse mellom energiforbruk og politiske forhold.

Nær sagt alle disse forholdene er berørt i Rimbereids fremtidsvisjon. Den overordnede endringen han skildrer i «Solaris korrigert», er overgangen fra en utopisk forestillingsverden til en dystopisk fremtid. Karbonepoken utviklet seg til en forblindelse om at det var energi nok til å produsere velstandsvekst som førte helt inn i himmelen. Dystopien er en postkatastrofisk tilstand der man planlegger å emigrere fra klodens overflate fordi livet der er truet. Det er knapt mulig å leve der mer. Målet for migrasjonen er Solaris - hos Rimbereid ikke en annen planet, men et undersjøisk samfunn:

AIG ne veit wat aig mein um mrs. Chan ennimeir.

HU haf naw vid 14.6 siner intern lovar

Bestimmen at nearli heila 14.6 ska til

Seifa botten flytta.

DEN ska «SOLARIS» kallast.

«SOLARIS»? Ne meir 14.6? (Rimbereid 2000, s. 35)

Den nye teknologien og redskapskulturen knyttet til fremtidssamfunnet hører vi om allerede i den innledende kursiverte teksten der det lyriske jeg henvender seg til verkets $\mathrm{du}$, som naturligvis direkte eller indirekte inkluderer leseren. Det frem- 
går at menneskene bruker redskaper som på en eller annen måte er organisk interpolert i kroppen. Dette kyborg-motivet er en del av science fiction-sjangerens motiv-vokabular. Det virker som om menneskene har en svekket yteevne:

(...) wi arbeiden

onli vid oren nanofingren,

(...) AIG seer an

meiner fingren, part af organic 14.6,

men veike, dei er som seagrass (s. 9)

Svekkelsen kan muligens forklare den utstrakte bruken av roboter som vi hører om flere steder i verket. Teknologien i fremtidssamfunnet er en blanding av nytt og gammelt. Nanofingre og roboter kan representere det nye, men mest oppsiktsvekkende blant de nye redskapene er Breynmachin BK2884, som befinner seg en kilometer under havet, i en tom oljebrønn. Maskinen har viktige funksjoner:

BK2884 er den best master

til ou biobalansera biosfæren,

og den best master af oren

ekonomical vorld, af taxes, trafficky, siddyplans

og best master af oren plans for future.

OREN organic- og siddy-

konnection kan ne lefa vidout denna breyn, dei seis.

STOPS BK2884 =

BIG risk for oren praktical vorld (s. 30).

Fortelleren står overfor at han snart skal ned til havbunnen for å arbeide med å skape en «NEW-DEPT-SEA-VORLD» under slam, sjøgress og fisk. Perspektivet er prekært:

(...) EIN slik seifa

vorld er kan henda

oren sista chans, dei seis.

OM wi skat enka intelligenten

og seifa uss self, som human existensen,

wi haf ou profa wat we profa kan (s. 31). 
Rimbereid legger imidlertid også vekt på at elementer fra gammel redskapskultur lever videre. Fortelleren har «grease» på hendene, gulsvart, glinsende grease, og han redegjør for at dette er elementer fra fortiden: «DEI er ne onli part af modern modell-/novledge. DEI er ogso part af old sea,/af old pipes og old grease» (s. 25).

Dette fører oss til arbeidslivet i fremtidssamfunnet. Fortelleren er arbeidsleder for et arbeidslag som består av 123 roboter. De arbeider under sjøen med å reparere rør og rørledninger. Selv virker arbeidsformannen som representant for menneskene redusert med hensyn til arbeidskraft. Det heter faktisk at menneskene, som altså arbeider ved hjelp av sine nanofingre, har en arbeidsdag som kun omfatter en halvtime: "wi arbeiden/so litl, 30 minutes a dag» (s. 9). Robotene arbeider derimot flittig. De er som maur, får vi vite (s. 25). De kalles «greipmaskinar», er rektangulære, og størrelsen blir oppgitt i millimeter: 1200 x 400 x 350 mm. De er koplet til hverandre i et nettverk, slik at arbeidet de utfører er totalkoordinert. De har en «kollktiven breyn» (s. 10). Hvis en av dem skulle gå i stykker, blir den straks erstattet av en ny (s. 25). Likevel vet de ikke om hverandre. De har et lukket feedback-system som gjør at «DEI only veit om seg self» (s. 10). Fortelleren sier han elsker sine roboter, og han påstår de er både fri og lykkelige - bare at de ikke er i stand til å vite det selv. De minner også om slavearbeidere, slik vi kjenner dem fra tidligere historiske epoker. De har ingen annen funksjon enn å utføre arbeid til beste for menneskene. Både kyborg-motivet og disse robotene kunne friste en til å dreie denne fremstillingen i posthumanistisk retning. Når det er et spor jeg ikke velger å følge i denne sammenhengen, er det fordi kyborg-motivet er et gammelt motiv innen science fiction-sjangeren, mye eldre enn den posthumanistiske retningen, og fordi robotene i den aktuelle sammenhengen inngår som en del av verkets klassesamfunn. Men at science fiction-fortellinger ofte utforsker endrede grenseflater mellom mennesker og maskiner, er et emne som kan invitere til utdyping av maskinenes plass $\mathrm{i}$ «Solaris korrigert».

Det er ikke fullstendig klart hva arbeidet under havet konkret går ut på. Robotene reparerer «hydropipes». Arbeidslederens ekspertise består i «mekanical novledg», og han skal, som sagt, bidra i arbeidet med å bygge en trygg verden under havet. I den sammenheng fremgår det at han skal pumpe "geotherminal energi» opp av havbunnen. I intervjuer har Rimbereid selv sagt at arbeidet $\mathrm{i}$ «Solaris korrigert» består i å utvinne varmeenergi fra kontinentalsokkelen under havbunnen. Hvorom allting er; det fremgår tydelig at menneskenes arbeidsliv er vesentlig forandret i fremtidssamfunnet. Rimbereid bruker et meget konkret virkemiddel for å få frem forandringen. Han endrer fullstendig på mål og tall: Arbeidsdagen er 30 minutter lang. 
Det samme virkemiddelet bruker han når han skal skildre de nye forholdene $\mathrm{i}$ transportsektoren. Vi får vite om raske reiser til både regio London og regio Moskw i løpet av verket. Og det går fort:

Ou fara avgarde

til regio London, i hoy hoy speed-

tunnel undr seaen

ovfr platfurmvrak

og olda, emti gassbrunnar

der unkring dark seagrass vexr (s. 28)

Hastighet og transportmåte blir også oppgitt konkret, og det er det og tall som sikrer underliggjøringen:

OG plutsl kenna speed, kenna startryck gennom

rygg og neck. MEN so, ven to minutter fara i $1490 \mathrm{~km} / \mathrm{h}$

i el-magnet-tunnel, all er som normal ...

SPEEDLOVEN: OU fara av garde

i eigen gravitation-room, fara forbi vrak og brunnar

og ne kraft kenna fra det,

onli kraft fra point long long der fram (s. 29)

Bomønstre og organisasjonsformer er også sterkt endret i Rimbereids fremtidsvisjon. Vi hører ingenting om nasjoner, bortsett fra i forbindelse med en regionsbetegnelse som «regio Norwg-West». Som samfunnsorganiserende enhet er nasjonen borte. Som nevnt er Solaris-språket bygget på den lokale stavangerdialekten, ikke på norsk offisielt skriftspråk, og innflytelsen som har frembrakt språkendringene, kommer fra regionene rundt Nordsjøen. Vi hører i sitatet ovenfor at kjente storbyer som London og Moskva omtales som regioner («regio London»). Det virker som om region er en størrelse som har fått økt betydning. Derimot gis det et ganske forfallspreget bilde av «siddy Stavgersand». De nye organisasjonsformene er åpenbart mindre enn de tradisjonelle byene. De betegnes som cells og organics:

SIDDY Stavgersand, siddy min,

exist nearli ne at all, mang

konklud naw. KAN henda den exist 
onli som ein olda namn, som symbol an ein siddy?

JA, som om places i 2480 forts sku wiktig vera!

STAVGERSAND, ein nearli

midt i flowen af so mang emti place

cells, organics, konnekts, pow og del-

lovar (s. 12).

Når det gjelder byen, er imidlertid bildet litt forvirrende. På den ene siden skildres den som «nearli emti». På den andre siden hører vi om «siddyens kaotic streets, proppa af humans» (s. 13). De viktigste boformene ser imidlertid ut til å være «organics». Fortelleren bor i organic 14.6. Den har 63000 innbyggere. Her bor han sammen med kjæresten Shri. De har et «litl room, eigat af organic 14.6». Det fins også mange andre organics, og de ser i hvert fall delvis ut til å være klassemessig differensierte. Antakelig bor det en parfymeduftende elite i organic 1.1 (s. 27).

Dette bringer oss til befolkningens sammensetning. Den er klart klassedelt. Øverst i systemet har vi verken konge eller president, men en (antakelig) kinesisk eier, Mrs. Chan. Også i omtalen av henne bruker Rimbereid mål- og tallforskyvning for å skape en underliggjort verden; Mrs. Chan er nemlig 123 år gammel. Fortelleren føler seg imidlertid ikke sikker på at Mrs. Chan overhodet er en person.

OG mrs. Chan er good organic-eigar.

MRS. Chan er 123 age, dei seis.

OG difor smart, vid big human novledg.

SELF om aig iblant tenk hu ne exist.

AIG tenk hun mang er, er ein sort firm.

OR kan henda hu ne human er,

men onli ein konstruct breyn

som ein human tenk? (s. 37)

Høyt i klassesamfunnet finner vi dem som blir kalt skuggar. De lever i organic 3.4 og tilsvarende organics. De kalles skuggar fordi de befinner seg bakenfor «all konstruction, production/all nummer, namn/og ideo». (s. 23) De lever avsondret, helt for seg selv, omgås bare hverandre og «tenkande onli i deirs eigne tank» (s. 24) Det er åpenbart at de er samfunnets elite: «DEI er novledg-/humans, vid staerkar pow enn all areal-/og materie-eigare. DEIRS pow/er unbegrensat, dei seis.» (s. 24) Fremtidssamfunnet har altså bevart motsetningen mellom hjernearbeidere og de 
som har «grease» på hendene. Motsetningen kommer imidlertid meget mildt til uttrykk: «TAKK so byr!» (s. 24). Den aktive klassekampen med streik som våpen, slik vi kjenner den ikke minst fra kullepoken, er åpenbart en saga blott.

Fortelleren tilhører en klasse som gjennomgående i verket kun kalles humans. Det er mulig han og hans klasse skal oppfattes som Solaris-samfunnets mellomklasse. I så fall må vi oppfatte det slik at mellomklassen har opplevd et betydelig klassefall siden oljeepoken. Som nevnt bor fortelleren sammen med sin kjæreste i en liten leilighet som tilhører den organic der de bor. Vi hører ikke om noen form for velstand eller luksus. Men det kommer kanskje an på om man betrakter 30 minutters arbeidsdager som luksus eller straff. (Selv heller jeg til det siste.) Vi får ingen inngående skildring av hvordan fortelleren eller hans befolkningsgruppe lever. Men vi hører om et helsesystem der fortelleren går og får sprøyter. Vi hører om hans tarminfeksjon. På et tidspunkt blir også hjernen hans skannet, og det blir slått fast at han lider av en defekt: «KONKLUTION: AIG haf ein litl/defect i venstr phantomic breyn-/bark, ein noko for staerk production/af eigne picts» (s 41). Den «human» vi stifter bekjentskap med som lesere, skal altså oppfattes som en slags dissident med litt for mange selvstendige forestillinger. Det er kanskje derfor han forteller oss fortellingen om «Solaris korrigert». I tillegg til disse helsemessige opplysningene er det gjort enkelte forsiktige forsøk på å menneskeliggjøre fortelleren og hans liv. Vi har allerede hørt at han har en kjæreste, Shin. Han forteller også at han av og til blir såret av hennes «bad bad ord» (s. 21). Han har minner om at faren bar ham på skuldrene sine, og han besøker sin mors gravsted. Men vi hører ikke om noen barn, til tross for at han er 38 år.

Lenger ned på rangstigen finner vi dem som blir kalt for drifters. De fremstår som en form for nomader, uten fast jobb og uten fast bosted. Det er drifters som fyller gatene i siddyen og gjør den kaotisk. Det synes også å være dem som blir utsatt for den mest aktive overvåkning og skolering eller «korrex». Det ser også ut til at det er liten kontakt mellom fortellerens klasse og drifters. I hvert fall sier fortelleren at han knapt kjenner noen drifters. Han har imidlertid kjennskap til enkeltpersoner som har fătt romantiske drømmer og har forsøkt å flytte ut i ødemarken for å leve i pakt med naturen. Dette er et motiv Rimbereid åpenbart er fascinert av. Han skriver også om det i Lovene. Disse romantikerne har også en brutal side. I «Solaris korrigert» hører vi om at en slik romantisk drifter har lokket med seg folk ut i ødemarken for å drepe dem der. ${ }^{2}$

2 Både Janneke Kampevold Larsen og Audun Lindholm ser en slags positiv frihet i drifters forhold til samfunnet. Det er lesninger jeg mener teksten som helhet gir svakt grunnlag for. De to blir da også fornuftig korrigert av Jenny Moi Vindegg i den meget innsiktsfulle masteroppgaven «Men du er óg en bølge.» Kropp og persepsjon i Øyvind Rimbereids lyrikk (UiO, 2014). 
Nederst på rangstigen i samfunnet befinner robotene seg. De utfører arbeid for humans og har stor kapasitet. De er under fullstendig kontroll og er konstruert slik at de utfører et gjennomført koordinert arbeid, uten å vite om hverandre. Fortelleren mener de er både fri og lykkelige. Men vi hører naturlig nok ingenting fra robotene selv. Det er uvisst ut fra fremstillingen hvordan roboter som mangler menneskelige forutsetninger, kan være lykkelige og fri. Kanskje skal det forstås som projiseringer fra fortelleren og hans klasse av humans.

Et påfallende trekk ved skildringen av fremtidssamfunnet i Solaris korrigert er at ingen spiser. Vi får ikke vite noe om næring, næringskjeder og hvordan mennesker og dyr skaffer seg mat. Vi får vite at det fins dyr, men at for eksempel elefanter ikke lenger kan leve i det fri. Men hvordan man dyrker spiselig næring, sier ikke fortellingen noe om. Brian Stableford skriver i artikkelen «Science fiction and Ecology» at i økologisk science fiction «the central thread of ecological analysis is the food chain, which extends from 'primary producers' which fix solar energy into various extended pathways whose links are herbivores, predators, parasites, and saprophytes» (Stableford 2005, s. 127). I et strengt sjangerperspektiv ville man kanskje mene at dette er et argument for å ikke betrakte «Solaris korrigert» som del av den økologiske fantastikken. Selv mener jeg likevel at oppmerksomhet på energi er et like relevant økologisk tema som næringskjeden - som jo også er koplet til energispørsmålet.

Rimbereid har berørt en rekke aspekter ved fremtidssamfunnet og vist at det ikke bare ligger én avgjørende Hendelse mellom nåtid og fremtid: Det at oljebrønnene er blitt tomme, har ført til en rekke grunnleggende og irreversible Hendelser også på andre samfunnsområder, Hendelser som leseren må «rekonstruere» $\mathrm{i}$ møte med verket. Det er neppe grunnlag i teksten for å rekonstruere disse hendelsene i konkret forstand. «Solaris korrigert» er ingen spådom, men et litterært verk. Det viktige poenget er at sammenhengen mellom energikilde og samfunnsstruktur er tett, og at konsekvensene av den historiske Hendelsen «Solaris korrigert» tar utgangspunkt $i$, er omfattende.

\section{SPRÅKET «KORRIGERT»}

Den langsomme hovedhendelsen som ligger til grunn for fremstillingen $\mathrm{i}$ «Solaris korrigert», den språklige endringen jeg nevnte innledningsvis, er naturligvis den viktigste faktoren som bestemmer diktets lydlige og rytmiske egenart. Den er knyttet til fremtidsperspektivet i verket. Det hybride språket er uttrykk for at vi befinner oss i en endret verden. Regionen utenfor «Norwg-West» er åpenbart langsomt blitt preget av økt samkvem. De peker sånn sett i retning av en felles 
fremtid. Enten vi leser «innenat» eller forsøker å lese teksten høyt, så «hører» vi et språklig og litterært uttrykk vi aldri har hørt før. Diktets sonore særegenhet er en konsekvens av de språklige konstruksjonene Rimbereid har skapt. Disse har åpenbart en tematiserende funksjon. Ved scenefremføring blir det sonore og musikalske aspektet på en måte dominant. Å høre Rimbereid selv lese teksten gir et genuint inntrykk nettopp fordi hele språkkonstruksjonen har utgangspunkt i stavangerdialekten. Da Det norske teateret satte «Solaris korrigert» i scene, leste skuespilleren Ane Dahl Torp teksten med østlandsk dialektpreg, noe som ga et ganske annet lydbilde. Det lød som fremtidsknoting.

Det spesielle med det sonore aspektet ved «Solaris korrigert» er at det gjør seg gjeldende på et mer primært språklig nivå enn det vanlige i norske tekster. Vanligvis er det sammenkjedingen av ord langs tekstforløpet som utgjør den sonore komposisjonen. I «Solaris korrigert» er det primære nivået selve ordnivået. Det komponeres ikke bare ved hjelp av allerede kjente ord. Allerede samlingens første linje opererer med tre (av fire) ord som er nylaget: «Wat vul aig bli» (s. 9). I tillegg til at dette inviterer til en nødvendig intuitiv «oversettelsesprosess», skaper det også en ny språkmusikk. Rimbereid komponerer på det syllabiske nivå i språket. Slik er det gjennom hele teksten. Ofte dreier det seg om lydlige endringer i velkjente ord, som i «wat vul aig». Men det fins også en god del neologismer, som for eksempel «skreikmare» (s. 9) som følger like etter åpningssetningen.

\author{
SKEIMFULL, aig trur, ven \\ du kommen vid diner imago \\ ovfr oren tiim, tecn, airlife, \\ all diner apocalyptsen \\ skreik- \\ mare. OR din beauti draum! NE \\ wi er. NE diner ideo! DER \\ aig lefr, i 14.6 wi arbeiden \\ onli vid oren nanofingren (s. 9)
}

«Skreikmare» må bety mareritt og knytter seg til det apokalyptiske perspektivet i diktet. Det kursiverte innledningsdiktet kan kanskje oppfattes som en henvendelse fra det lyriske jeget til oss som lever i en annen tid. Henvendelsen i diktet blir på den måten historisk overskridende. Det kan kanskje leses som en advarsel fra fremtiden. Det er tydelig at jeget føler skam ved å bli betraktet av den som skuer inn i fremtiden, skam over endringer som har skjedd. For eksempel når det gjelder utholdenhet og styrke. Utropstegnene er også med på å dramatisere ved å legge 
emosjonell emfase på utsagnene. Den emosjonelle ladingen er med på å definere den første teksten i samlingen som en prolog. Det samme gjør også bruken av kursiv. Slik emosjonell emfase preger nemlig ikke diktets hovedtekst, der det fortelles om ganske dramatiske forhold på en ganske cool og konstaterende måte.

Bruken av versaler ser ut til å være grammatisk bestemt. I Solaris-språket skrives hele det første ordet etter full stopp med store bokstaver, ikke bare forbokstaven i ordet.

SO ku aig begg din vorld

begynning, start uss

up igjen? KU det!

SKEIMFULL aig er. SO

wat

vul du bli

om wi ku kreip fra

uss til deg (s. 9-10)

Prologdiktet inviterer til en tenkt dialog mellom oss som lever i vår tid, og fremtidens folk. «Diner imago» og «din beauti draum» fungerer mest som en kontrast til det skremmebildet teksten representerer.

\section{LYRISKE BILDER}

Som science fiction-fortelling signaliserer «Solaris korrigert» tradisjonelle sjangertrekk som underliggjort fremtidsperspektiv, urovekkende apokalyptiske eller dystopiske utviklingstrekk og teknologiske nyvinninger eller endringer. Blant de teknologiske aspektene finner vi ikke bare roboter og maskiner, som jeg allerede har nevnt, men også en retorisk bruk av tall som signaliserer science og presisjon. Tallene gir ofte liten mening utover det retoriske signalet de sender til leseren om vitenskapelighet og faktaorientering. Dette signalet er i «Solaris korrigert» viktigere enn tradisjonelle lyriske elementer som metaforer og litterære bilder. Likevel får vi gjennom en helsesjekk vite at jeget i fortellingen har et avvik i hjernestrukturen som resulterer i en overutviklet forestillingsevne. Dette samsvarer med, og gir kanskje også en forklaring på, hvorfor denne arbeidsformannen i en undersjøisk industrivirksomhet skriver dikt. Han produserer «eigne picts». Teksten er likevel i relativt liten grad preget av billedbruk. Det forekommer enkelte lokale metaforer som «lovens tarmar» (s. 15), fingre omtales som sjøgress, og robotene er som maur. Et lite avsnitt om fisk i stim (s. 31-32) skal nok oppfattes konkret, men har dog et 
metaforisk potensial i forhold til et begrep omtalt ellers i samlingen, nemlig «kollectiven breyn» (s. 10). I tillegg har vi allerede hørt at noen av de sosiale klassene i samfunnet har fått betegnelser som impliserer metaforisk mening (skuggar og drifters). Utover disse forekomstene er det først og fremst to billedlige forestillinger som spiller en sentral rolle i verket. Den ene har med lys og lysrefleksjon å gjøre; den andre knytter seg til gravitasjonskraften som basisprinsipp i tilværelsen. Begge disse forestillingskretsene peker mot grunnleggende sammenhenger i eksistensen.

Lysmetaforikken møter vi først via satellittbilder av jordkloden ved natt. ${ }^{3}$ På slike bilder avtegner det geografiske kartet seg ganske vagt, mens lysene fra byene blir tydelige. Billeddannelsen hos Rimbereid tar utgangspunkt $i$ at dette nattlyset fra Kristiansand til Bergen danner en sigd:

SOMTIIMS aig find og seer an min screen, seer an regio Norwg-West, picts takat fra ofven, seer all ljus om natt, spots eftr spots so tait og komplex, fra Krisand til Bergn.

SPOTS af ljus i ein sigd, som om all saman hengr. EIN sigd klar til ou skera gennom all materie og all human life (s. 11).

Bildet utvides dernest globalt med Kina som eksempel (Chin), der lyskildene, det vil si byene, knapt kan skilles fra hverandre. Sigdene blir nå til halvmåner som det ikke er like enkelt å se for seg som sørvestlands-sigden.

(...) I Chin f. ex.,

der ne siddy kan skillast out,

der infinit mengd af sigd i ljus er.

OG liksom uppo kverodder,

i ein gigant pattern,

vanskl ou vita wat all sigdar tilsamman blir...

OR seer out som half moons, detta? SOM big mengd half moons

3 Dette bildet er også grundig analysert av Jenny Moi Vindegg i masteroppgaven «Men du er óg en bølge.» Kropp og persepsjon i Øyvind Rimbereids lyrikk (UiO 2014). Hun legger imidlertid hovedvekt på de kroppslige og sanselige aspektene ved fremstillingen. 
up ner, vid jord undr seg

vid oren jord som ein dark, infinit

univers undr seg? (s. 11)

På toppen av denne billedutvidelsen plasseres så en allegoriserende fundering vedrørende den store sammenhengen i universet:

JA, er det detta wi er?

EIN vorld af half moons?

MEN wat er da oren sol? (s. 11)

Denne sol-måne-relasjonen dukker opp igjen i skildringen av drifters, den nomadiske klassen i samfunnet, de som er uten «seifa system» omkring seg (s. 14), men som likevel er en del av samfunnet og blir straffet for selv ganske små forseelser (s. 15). Kanskje er det ensomheten i drifters' eksistens dikteren vil skildre når han karakteriserer dem som isolerte soler uten noen måne å skinne på:

DEI er openbara,

hengr umkring som solar.

SOLAR vidout moons ou skinna mot? (s. 14)

Siste ledd i denne billedkretsen er kroppslig. Diktets jeg har en gang hatt tarminfeksjon, og i den forbindelse har han åpenbart tatt røntgenbilder av sin «bottentorso». Han har flere ganger senere betraktet sitt røntgenbilde og oppdaget at hoftebeina også ligner sigder eller halvmåner. Denne likheten får ham til å fundere over forvirrende sammenhenger i tilværelsen. Noe i ham selv er bare halvveis hans eget, halvveis noe annet, «SOM om dei lefr/siner heilt eigne lifs i meg?» (s. 16) Dette som er halvt noe annet i ham selv, er noe han ikke har kontroll over:

OG ven dei sjuk blir,

kan henda til det doyande,

min breyn kan ne helpa dei (s. 16).

Han har imidlertid ikke noe svar på hva dette andre er. Billedbruken gjennomgående i diktet formidler en sammenheng mellom globale strukturer og kroppslige egenskaper på individnivå. 
Den andre billedkretsen i samlingen, gravitasjonsmetaforikken, formidler noe av den samme sansen for grunnleggende sammenhenger hos dikteren. Han erklærer gravitasjonskraften som et allestedsnærværende prinsipp i verden.

WAT ne forsvinna kan, er gravitationen. GRAVITATIONEN

existen ovfr all distans fra mill

sol-agen away

og strick back til uss.

LITL so litl, veik so veik, men ne zero. GRAVITATIONEN

er det minsta wi kan stola an.

DEN er den onli total

kommunicationen i univers (s. 21).

Prinsippet er ikke begrenset til universets sfæriske systemer. Det gjelder også på det sosiale nivå. Menneskene graviterer mot hverandre. På den måten er gravitasjonen også grunnprinsippet for individenes følelser av kjærlighet og hat.

DEN arbeiden ogso i uss.

ALL haf wi

kroppar, tick tock

gravitation-

i oren celln og knokl.

ALL wi arbeiden, all wi spiik: gravitationen.

VEN wi love og hatr: gravitationen (s. 21).

«Solaris korrigert» handler altså ikke bare om et fremtidig, dystopisk samfunn og om oljevirksomheten i Nordsjøen. Underveis pekes det også på grunnleggende universelle krefter som danner sammenhenger i tilværelsen ved hjelp av lyriske billedstrukturer.

«Solaris korrigert» viser Øyvind Rimbereids store spennvidde som forfatter og lyriker. Han er blant våre mest originale språkkunstnere, noe han viser både ved å konstruere et helt nytt språk og ved å være i stand til å bruke det konsekvent så vel grammatisk som lyrisk. Samlingen viser også Rimbereids repertoar som versdikter og billedskaper. Som det vil fremgå av gjennomgangen av senere dikt, står bruken av disse virkemidlene $\mathrm{i}$ «Solaris korrigert» $\mathrm{i}$ en utviklingskjede der forfatteren etter hvert fremstår som mer og mer dristig. 
Samtidig med fremvisningen av en original språkkunstner demonstrerer «Solaris korrigert» også at Rimbereid er en engasjert forfatter, dypt opptatt av sin egen samtids store utfordringer. Han retter blikket - kunstnerblikket - mot historiske hendelser og tematiserer endringer, irreversible endringer med konsekvenser for samfunn og eksistens.

\section{FELLES NÅTID - FELLES NÅDETID}

Da Hannah Arendt i 1957 skrev sin artikkel om en felles nåtid, var det i en presentasjon av Karl Jaspers verdensborgerskapsbegrep. Ideen om et verdensborgerskap ble lansert av Immanuel Kant i 1784 som en mulighet i en fjern fremtid. Arendt avviser heftig enhver idé om noen slags verdensstat eller et verdensimperium. Hun ser for seg et mulig tyrannisk mareritt. Hun så også at fremtidsvisjonen om et verdensborgerskap langt på vei var blitt korrumpert ved at Europa hadde «pålagt alle andre kontinenter sine love» (s. 47). Dette skjedde, mente hun, etter at Europa selv «allerede hadde mistet troen på dem» (s. 47), og dermed kom til å «eksportere sine oppløsningsprocesser til alle verdenshjørner» (s. 47). Hun var likevel klar over at den teknologiske utviklingen som hadde «frembragt verdens enhed, [...], lige så let [kunne] ødelægge den» (s. 48). Med andre ord var det skapt en solidaritet som var «baseret på frygten for global destruktion» (s. 48). Det er denne «negative solidaritet» (s. 48) hun prøver å vende over i et positivt spor ved hjelp av Karl Jaspers verdensborgerbegrep og hans idée om en «grenseløs kommunikation» mellom kulturer og tradisjoner, samt politisk ansvar. Som nevnt var Arendts kriseopplevelse skapt av atombombetrusselen. I miljøbevegelsens «first wave»-engasjement var det ikke minst overbefolkningsproblematikken som vekket til engasjement. I vår egen tid er det ikke minst global oppvarming og destruksjon av livsmangfoldet som skremmer. Vår nye kriseopplevelse og vår nye wave av engasjement gjør at vi fremdeles befinner oss i en «felles nåtid» - forstått som nådetid. Etter mitt skjønn er litterære verk som Rimbereids «Solaris korrigert» med på å minne oss om dette.

\section{LITTERATUR}

Andersen, P. T. (2018). Rimbereids lyrikk. Hendelser og poetiske øyeblikk. Bergen: Fagbokforlaget. Denne artikkelen er en revidert versjon av kapitlet om «Solaris korrigert» i denne monografien. Arendt, H. (2010). Eksistens og religion. Toenkning mellem Tradition og modernitet. Århus: Forlaget Klim.

Buell, L. (1995). The Environmental Imagination: Thoreau, Nature Writing, and the Formation of American Culture. Cambridge Massachusets. 
Burns, T. (2008). Political Theory, Science Fiction, and Utopean Literature. Ursula K. Guin and The Dispossesed. New York \& Toronto: Lexington Books.

Faldbakken, K. (1974). Uår. Aftenlandet. Oslo: Gyldendal.

Faldbakken, K. (1976). Uår. Sweetwater. Oslo: Gyldendal.

Garrard, G. (2012). Ecocriticism. New York: Routledge.

Gordin, M. D. et al. (2010). Utopia/Dystopia. Conditions of Historical Possiblity. Princeton: Princeton University Press.

Kunnskapsløftet 2020. Utdanningsdirektoratet.

Madsen, C. K. (2015). To aspekter af helhed og to typer langdigte. En afprøvning af Jacobsons poesiformalisering på Høeks «Ulrike Marie Meinhof» og Rimbereids «Solaris korrigert». Edda. Vol. 102, 04, s. 296-311: Oslo: Universitetsforlaget.

Mitchell, T. (2010). Hydrocarbon Utopi”. I M. D. Gordin et al., Utopia/Dystopia. Conditions of Historical Possiblity, s. 117-150. Princeton: Princeton University Press.

Norheim, T. (2015). «Picts af univers parallell». Om samtidslyrikk i Norge 2000-2010. I Karlsen, O. (red.) (2015). Nordisk samtidspoesi: Saerlig Jo Eggens forfatterskap, s. 9-40. Oslo: Novus.

Næss, A. (1973). Økologi, samfunn og livsstil. Oslo: Universitetsforlaget.

Refsum, C. (2010). Flerspråklighet i nyere skandinavisk litteratur. Johannes Hassan Khemiri og Øyvind Rimbereid. Edda.Vol. 110, 2. 81-96: Oslo: Universitetsforlaget.

Rimbereid, Ø. (2000). Seine topografiar, Trådreiser, Solaris korrigert. Oslo: Gyldendal.

Seed, D. (2005). A Companion to Science Fiction. Malden, Oxford, Victoria: Blackwell publishing. Stableford, B. (ed.) (2005). Science Fiction and Ecology. I D. Seed, A Companion to Science Fiction, s. 127-141. Malden, Oxford, Victoria: Blackwell publishing.

Vindegg, J. M. (2014). «Men du er óg en bølge.» Kropp og persepsjon i Øyvind Rimbereids lyrikk (Masteroppgave). Universitetet i Oslo. 